\title{
A Computational Methodology for Simulating Thermal Loss Testing of the Advanced Stirling Convertor
}

Terry V. Reid, Scott D. Wilson, Nicholas A. Schifer, and Maxwell H. Briggs

Glenn Research Center, Cleveland, Ohio 


\section{NASA STI Program . . . in Profile}

Since its founding, NASA has been dedicated to the advancement of aeronautics and space science. The NASA Scientific and Technical Information (STI) program plays a key part in helping NASA maintain this important role.

The NASA STI Program operates under the auspices of the Agency Chief Information Officer. It collects, organizes, provides for archiving, and disseminates NASA's STI. The NASA STI program provides access to the NASA Aeronautics and Space Database and its public interface, the NASA Technical Reports Server, thus providing one of the largest collections of aeronautical and space science STI in the world. Results are published in both non-NASA channels and by NASA in the NASA STI Report Series, which includes the following report types:

- TECHNICAL PUBLICATION. Reports of completed research or a major significant phase of research that present the results of NASA programs and include extensive data or theoretical analysis. Includes compilations of significant scientific and technical data and information deemed to be of continuing reference value. NASA counterpart of peer-reviewed formal professional papers but has less stringent limitations on manuscript length and extent of graphic presentations.

- TECHNICAL MEMORANDUM. Scientific and technical findings that are preliminary or of specialized interest, e.g., quick release reports, working papers, and bibliographies that contain minimal annotation. Does not contain extensive analysis.

- CONTRACTOR REPORT. Scientific and technical findings by NASA-sponsored contractors and grantees.
- CONFERENCE PUBLICATION. Collected papers from scientific and technical conferences, symposia, seminars, or other meetings sponsored or cosponsored by NASA.

- SPECIAL PUBLICATION. Scientific, technical, or historical information from NASA programs, projects, and missions, often concerned with subjects having substantial public interest.

- TECHNICAL TRANSLATION. Englishlanguage translations of foreign scientific and technical material pertinent to NASA's mission.

Specialized services also include creating custom thesauri, building customized databases, organizing and publishing research results.

For more information about the NASA STI program, see the following:

- Access the NASA STI program home page at http://www.sti.nasa.gov

- E-mail your question via the Internet to help@ sti.nasa.gov

- Fax your question to the NASA STI Help Desk at $443-757-5803$

- Telephone the NASA STI Help Desk at 443-757-5802

- Write to: NASA Center for AeroSpace Information (CASI) 7115 Standard Drive Hanover, MD 21076-1320 


\section{A Computational Methodology for Simulating Thermal Loss Testing of the Advanced Stirling Convertor}

Terry V. Reid, Scott D. Wilson, Nicholas A. Schifer, and Maxwell H. Briggs Glenn Research Center, Cleveland, Ohio

Prepared for the

9th International Energy Conversion Engineering Conference (IECEC) sponsored by the American Institute of Aeronautics and Astronautics San Diego, California, July 31 to August 3, 2011

National Aeronautics and

Space Administration

Glenn Research Center Cleveland, Ohio 44135 


\section{Acknowledgments}

This work is funded through the National Aeronautics and Space Administration (NASA) Science Mission Directorate and the Radioisotope Power Systems Program Office.

This report contains preliminary findings, subject to revision as analysis proceeds.

Trade names and trademarks are used in this report for identification only. Their usage does not constitute an official endorsement, either expressed or implied, by the National Aeronautics and Space Administration.

Level of Review: This material has been technically reviewed by technical management.

Available from

NASA Center for Aerospace Information 7115 Standard Drive

Hanover, MD 21076-1320
National Technical Information Service 5301 Shawnee Road Alexandria, VA 22312

Available electronically at http://www.sti.nasa.gov 


\title{
A Computational Methodology for Simulating Thermal Loss Testing of the Advanced Stirling Convertor
}

\author{
Terry V. Reid, Scott D. Wilson, Nicholas A. Schifer, and Maxwell H. Briggs \\ National Aeronautics and Space Administration \\ Glenn Research Center \\ Cleveland, Ohio 44135
}

\begin{abstract}
The U.S. Department of Energy (DOE) and Lockheed Martin Space Systems Company (LMSSC) have been developing the Advanced Stirling Radioisotope Generator (ASRG) for use as a power system for space science missions. This generator would use two high-efficiency Advanced Stirling Convertors (ASCs), developed by Sunpower Inc. and NASA Glenn Research Center (GRC). The ASCs convert thermal energy from a radioisotope heat source into electricity. As part of ground testing of these ASCs, different operating conditions are used to simulate expected mission conditions. These conditions require achieving a particular operating frequency, hot end and cold end temperatures, and specified electrical power output for a given net heat input. In an effort to improve net heat input predictions, numerous tasks have been performed which provided a more accurate value for net heat input into the ASCs, including the use of multi-dimensional numerical models. Validation test hardware has also been used to provide a direct comparison of numerical results and validate the multi-dimensional numerical models used to predict convertor net heat input and efficiency. These validation tests were designed to simulate the temperature profile of an operating Stirling convertor and resulted in a measured net heat input of 244.4 W. The methodology was applied to the multi-dimensional numerical model which resulted in a net heat input of $240.3 \mathrm{~W}$. The computational methodology resulted in a value of net heat input that was 1.7 percent less than that measured during laboratory testing. The resulting computational methodology and results are discussed.
\end{abstract}

\section{Nomenclature}

ASC Advanced Stirling Convertor

ASRG Advanced Stirling Radioisotope Generator

BOM Beginning of Mission

CSAF Cold Side Adapter Flange

DOE Department of Energy

EOM End of Mission

GRC Glenn Research Center

$\mathrm{HH} \quad$ heater head (watts/m-K)

$\mathrm{Q} \quad$ heat transfer ( $\mathrm{W}$ or watts)

$\mathrm{R}_{\mathrm{TH}} \quad$ thermal resistance (degrees $\mathrm{C}$ per watt)

$\mathrm{T}$ local temperature (degrees $\mathrm{C}$ or $\mathrm{K}$ )

TP thermocouple probe

TS thermocouple surface mount

SR Stirling rod 


\subsection{Introduction}

Power conversion using free-piston Stirling engines to deliver power at high efficiency and low mass continues to be an appealing option for long duration deep space missions (Ref. 1). An application that utilizes the free-piston Stirling engine is the Advanced Stirling Convertor (ASC), which is shown in Figure 1. Numerous efforts are currently underway the NASA GRC to verify performance and assess durability of the ASC (Refs. 2 to 5). These efforts include experimental and computational analysis of the ASC hardware.

During the early stages of development, a third order analysis was used to design the ASC so that it would perform in accordance with pre-determined criteria. A third order analysis uses control volumes or nodes to directly solve the one-dimensional governing equations (Ref. 6). In this case, the ASC was built based on the results of the one-dimensional solver SAGE (Refs. 7 to 9). SAGE solves the governing equations implicitly in space and time. The SAGE grid includes all time since the periodic solution is assumed/forced. As a result, it is not possible for SAGE to model startup transient behavior. SAGE output provides performance details as well as geometric and material details, allowing a prototype to be built. Once it is built, the performance is verified through a series of experimental and computational analyses.

Instrumentation exists inside the prototype ASC hardware that provides information regarding the motion of some of the internal components. However, quantities such as the Stirling cycle heat addition and general heat distributions are difficult to verify. These quantities are needed to define the net heat input, which is used to assess the performance of the convertor. A definition for net heat input is shown in Equation (1).

$$
\mathrm{Q}_{\text {net-heat-input }}=\mathrm{Q}_{\text {gross-heat-in }}-\left(\mathrm{Q}_{\text {cold-end loss }}+\mathrm{Q}_{\text {heat-rejected }}+\Sigma \mathrm{Q}_{\text {environment-heat-loss }}\right)
$$

The net heat input represents the heat that is used by the Stirling cycle. A portion of this heat is converted into mechanical power (Ref. 10), which then is used to generate electrical power. Knowing these heat quantities allow the overall convertor performance to be calculated, while knowledge of the internal temperature distribution provides information to assess the durability of the convertor's internal components. These are important parameters that help verify the convertor's performance. Expected convertor thermal loadings are shown in Figure 2.

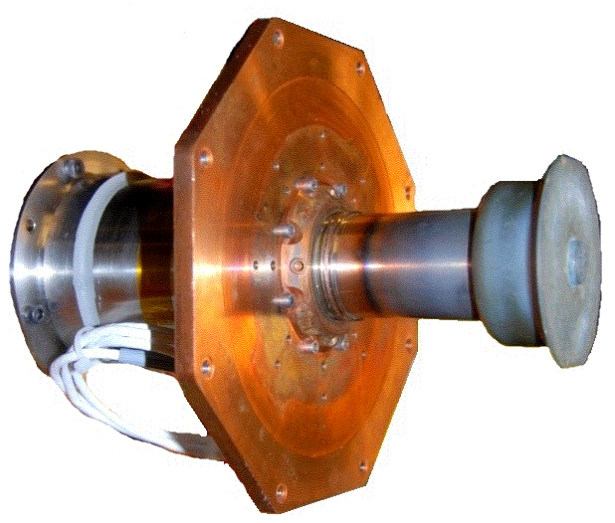

Figure 1.-Advanced Stirling convertor.

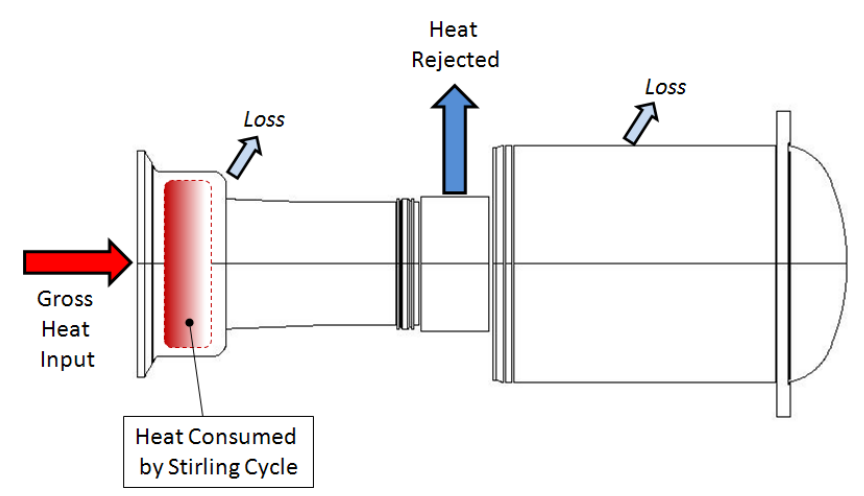

Figure 2.-Typical ASC thermal loads. 


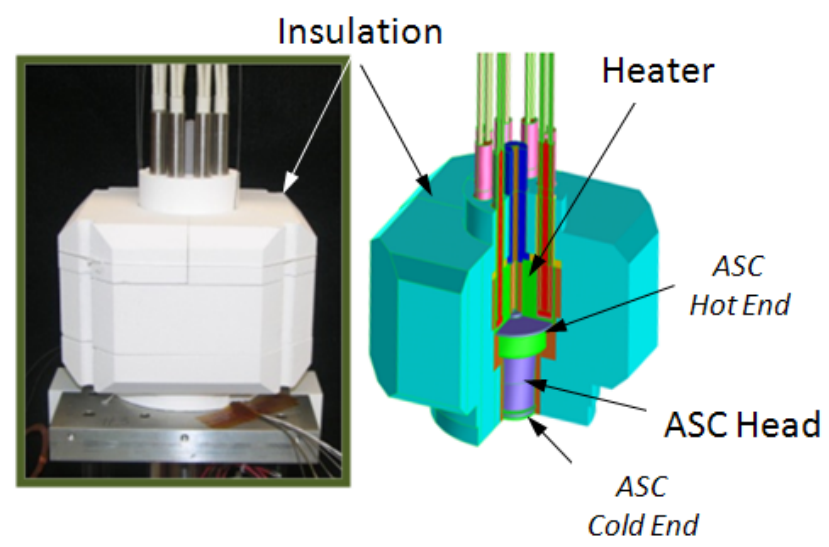

Figure 3.-ASC experimental test assembly.

In this document, Computational Fluid Dynamics (CFD—a fourth order multi-dimensional analysis technique) is used to calculate the thermal distributions. The CFD solver FLUENT (by ANSYS Inc.) was chosen because of its ability to include conjugate heat transfer and sliding mesh interfaces (when needed) during the inevitable transient calculations. There are different computational approaches that can be applied using FLUENT to calculate the behavior of the ASC convertor. They include solutions of:

1. The steady-state Navier-Stokes equations-This can provide a conservative estimate of the heat distribution thru out the convertor. Heat distribution along with the temperature distribution allows the temperature limits of the internal components to be evaluated and coarse heat quantities to be calculated. Although convection would not be present in this calculation, the sum of conduction and convection could be accounted for by tuning the computational model so that the internal temperatures match the measured data.

2. The unsteady Navier Stokes equations-This can provide a time-dependent history of the net mechanical power produced by the motion cycle which, when combined with experimental measurements of electrical power, can provide an estimate of efficiency. This time-dependent solution would also show the gas flow physics that are occurring inside of the convertor during operation.

In the Stirling Research Laboratory at the NASA GRC, the typical experimental assembly for testing consists of an ASC and a heating package (to provide gross heat input to the Stirling cycle by means of an electric heater), both of which are encapsulated inside of an insulation package. Although the insulation package helps to minimize the amount of heat lost to the environment, it does not totally eliminate it. The ASC experimental test assembly is shown in Figure 3.

Experimental tests using the ASC were conducted to gather temperature data along the perimeter of the insulation package, as well as at a variety of location along the insulation-convertor contact interface. The measured external temperatures were used as boundary conditions for a three-dimensional computational model of the ASC test assembly. As calculations were performed, the internal temperatures were monitored and the model tuned until the calculated internal temperatures matched measured experimental data.

When performing computational simulations of the Advanced Stirling Convertor hardware version E2 (ASC E2), there tend to be two unknowns:

1. The thermal conductivity of the external insulation, which is Microsil Type 2. This is a micro porous insulation that undergoes shrinkage as it is aged, increasing the thermal conductivity over time.

2. The net heat input consumed by the Stirling cycle. 


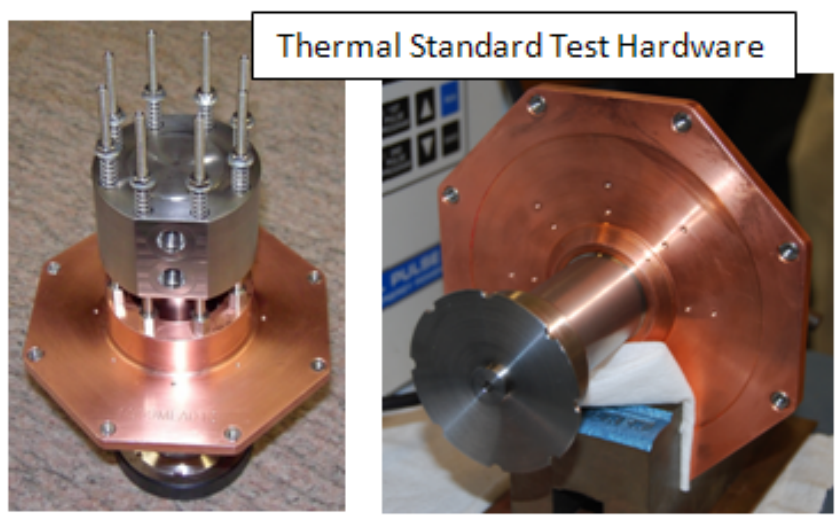

Figure 4.--Thermal standard hardware.

The measured gross heat is applied to the internal volumes representing the heater in the computational model. When measured external temperatures are applied to the external surface of the insulation package in the computational mode, this provides a value for the amount of heat exiting the insulation and going into the laboratory environment. With a combination of the applied gross heat, the insulation heat loss to the environment, and the matching of internal temperatures with measurements, the net heat input can be calculated. For the convertor calculations, the net heat input consists of the Stirling cycle heat and the heat exiting the convertor at the cold end.

For the ASC, there is presently no solid way to confirm the net heat input value that results from the solution of the computational model. As a result, another model called the Thermal Standard (shown in Fig. 4), was designed to verify the methodology used for the convertor calculations. The Thermal Standard has no moving parts and is made to simulate the thermal distribution that was observed during ASC-E2 experiments. Instead of a heat rejection via the Stirling cycle (conversion of thermal energy to mechanical energy), a highly conductive stationary rod is instead used to remove heat from the assembly during testing. The material of the highly conductive rod (GRCop-84) (Ref. 11), and its dimension were chosen so that the rod would remove by conduction) the same quantity of heat expected to be consumed by the Stirling cycle during its nominal operation. With the Thermal Standard, this verifiable heat quantity is a valuable quantity for the verification and validation of the methodology.

The computational approach used was a two-step calculation methodology that includes solving two separate simulations. Analogous to the "two equations, two unknown" scenario that occurs frequently in mathematics, this computational strategy is utilizing two simulations to solve for the two unknowns. Measured lab data from insulation loss testing (simulated non-operating) of the Thermal Standard is used as boundary conditions in the first step of the solution strategy, to define the instantaneous thermal conductivity profile of Microsil Type 2. Then, this newly acquired Microsil Type 2 thermal conductivity profile is held fixed in the second simulation (simulated operation), where a finite amount of heat is rejected by the highly conductive copper rod. The solution of this second simulation produces the ultimate result, which is the net heat input.

This document describes the details of the methodology that was applied to both the ASC and the Thermal Standard computational models, but focuses on the Thermal Standard. It also discusses how the Thermal Standard was used to estimate the error associated with using a two-step methodology to calculate net heat input. These efforts are on-going. 


\subsection{Assembly}

Figure 5 shows the CAD model of the Thermal Standard. Although there are slight material changes that differentiate it from the ASC (Ref. 12), the materials were chosen so that the temperatures distributions throughout both are very similar. For the computational model, this geometry was cut and some of the volumes beyond the Cold Side Adaptor Flange (CSAF) were eliminated. This includes the fluid heat exchanger. Detailed hardware measurements were available in this area, and eliminating the unwanted volumes helped the calculations run faster.

The materials that make up the Thermal Standard were divided in three groups. These groups include the Thermal Standard, the Heating Package, and the Insulation Package.

\subsection{Thermal Standard}

Figure 6 shows the contents of the Thermal Standard materials. Throughout the calculation sequences, the temperature-dependent thermal conductivity profiles are unchanged.

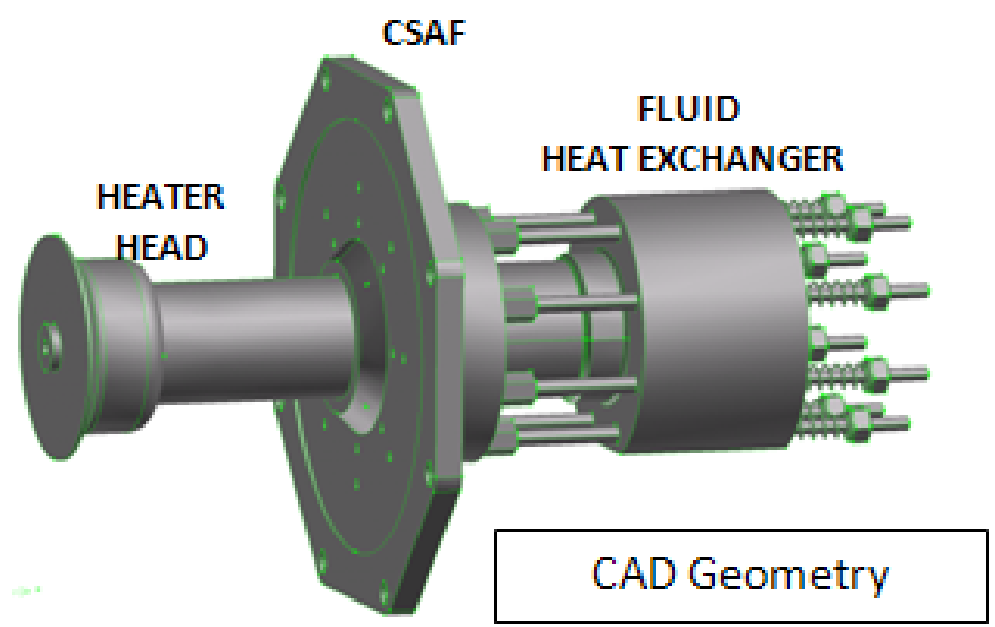

Figure 5.-Thermal Standard geometry.

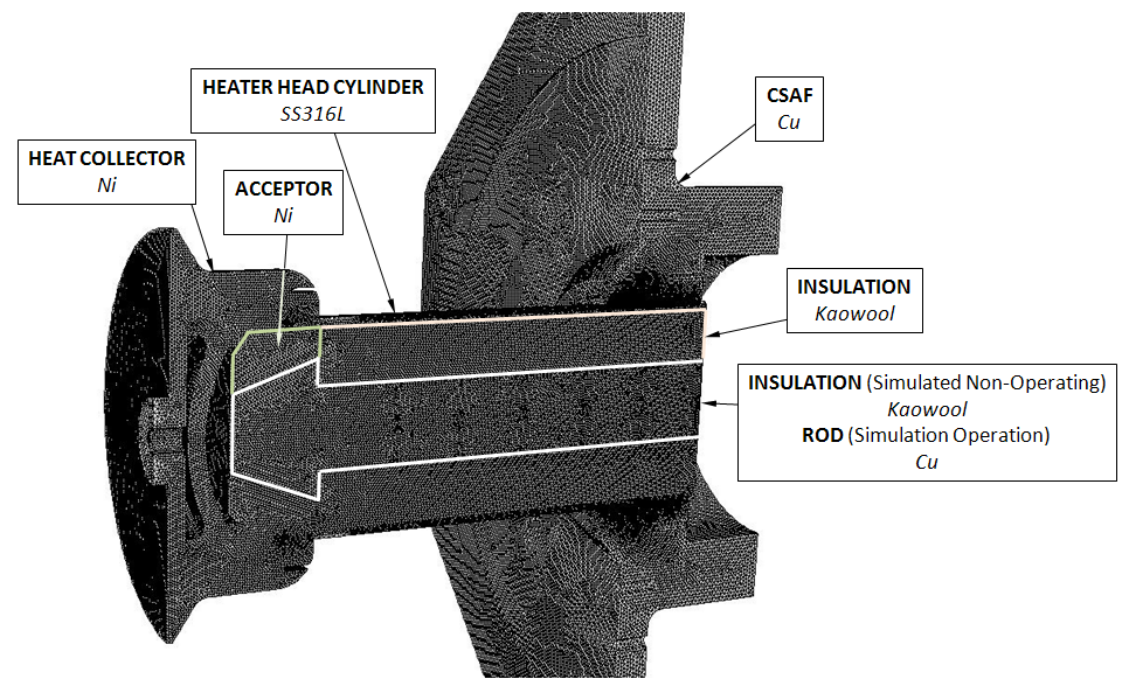

Figure 6.-Thermal Standard components. 


\subsection{Heating Package Materials}

Figure 7 shows the contents of the heating package. Throughout the calculation sequences, these temperature-dependent thermal conductivity profiles are also unchanged.

\subsection{Insulation Package Materials}

Figure 8 shows the contents of the insulation package materials. During the calculations, the Microsil thermal conductivity is modified in an effort to adjust the absolute values of the internal temperatures. At the beginning of the calculations, the internal temperatures are always high. Because of the behavior (shrinkage) of the Microsil, increasing the thermal conductivity is considered a realistic adjustment.

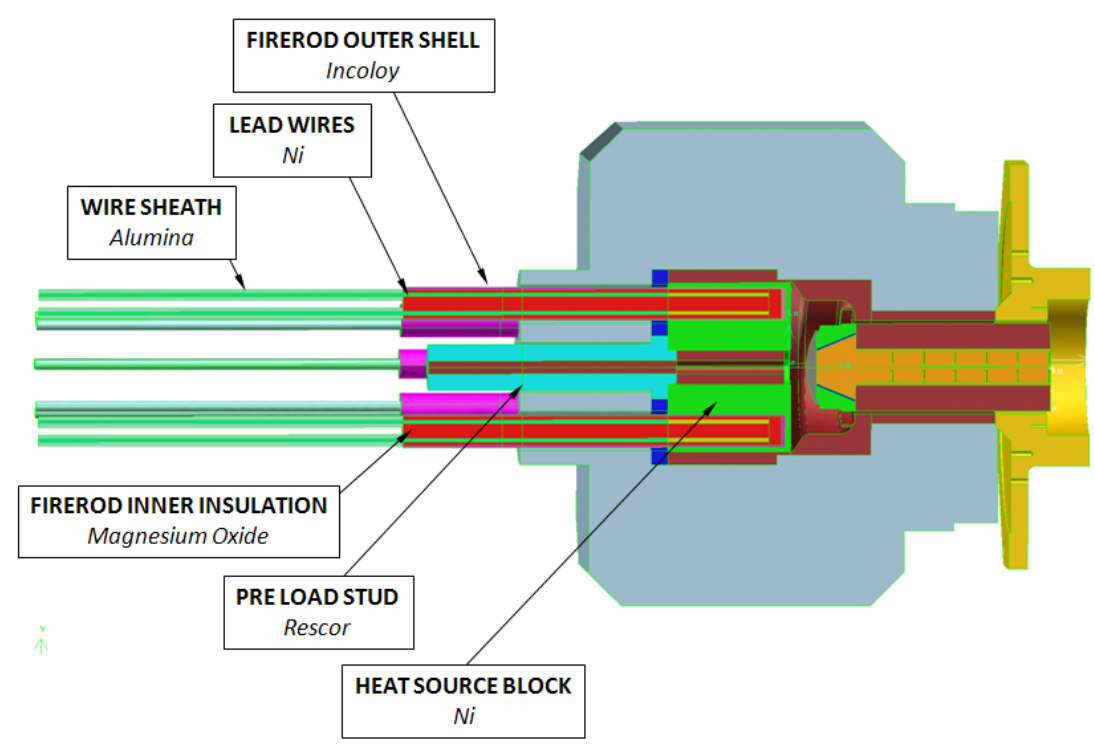

Figure 7.-Heating package materials.

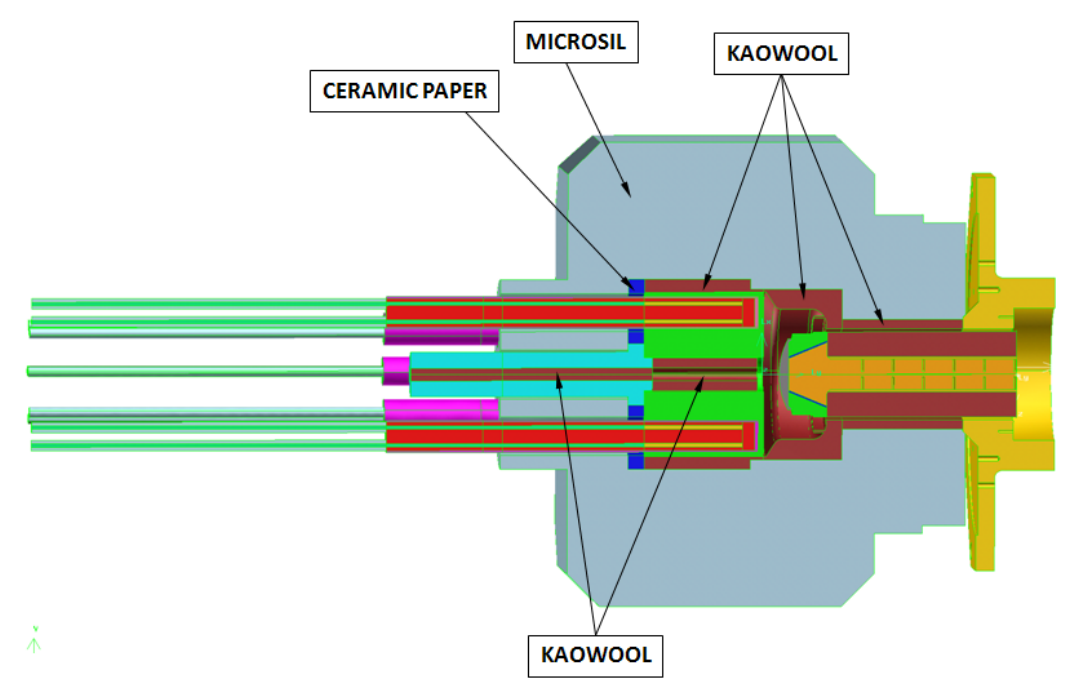

Figure 8.- Insulation package materials. 


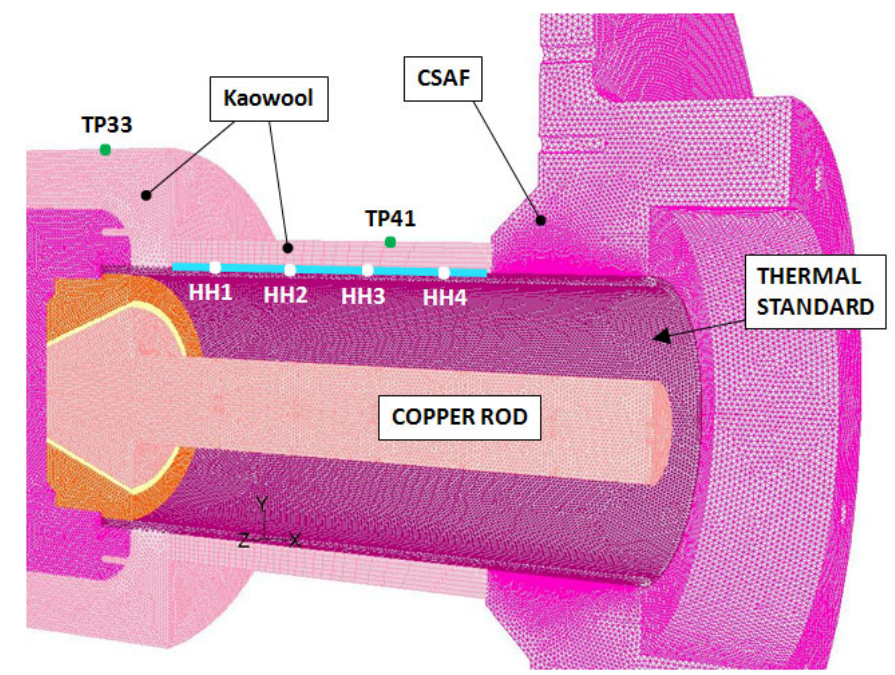

Figure 9.-Location of Kaowool insulation.

Microsil is a micro-porous insulation that experiences volumetric shrinkage (and an increase in thermal conductivity) when heated. When it arrives at the GRC Stirling Lab, it is typically baked at $850{ }^{\circ} \mathrm{C}$ for $24 \mathrm{hr}$, which causes it to undergo 80 percent of its maximum anticipated shrinkage.

With continued baking, the rate of shrinkage decays asymptotically. However, the bake time required to eliminate all of the shrinkage becomes time prohibitive. The first step in the calculations is aimed at defining the instantaneous thermal conductivity at the time the experimental test temperatures were collected.

Numerous experimental tests have been performed with Microsil Type 2 to define its thermal conductivity. One of the available measured thermal conductivity profiles was provided by Thermophysical Properties Research Lab (TPRL) for aged Microsil Type 2. At the end of the Insulation Loss calculations, the thermal conductivity of Microsil had to be increased by 5 percent above the measured value provide by TPRL, to match the experimental measurements.

There are three grades of Kaowool that are available for the laboratory tests. These three grades differ in thermal conductivity by $\sim 10$ percent. The Kaowool is packed around the perimeter of the heater block and the actual Thermal Standard (or ASC). Its location is shown in Figure 9.

There are contact resistances between the Thermal Standard and the Kaowool, as well as between the Kaowool and the Microsil. This exists in the form of a slight air gaps or imperfect contact between nonsmooth surfaces. This is not directly accounted for in the model setup since the surface roughness and pressure of application would be needed. Instead, the thermal conductivity of Kaowool is modified by small amounts to reflect the existence of the contact resistance.

Figure 10 shows a thermal resistance schematic of the Kaowool and the other materials that it is in contact with adjacent to the Thermal Standard heater head cylinder wall. Looking at Equation (2), if contact resistance is assumed to be zero (perfect contact with no air gaps), then the effective thermal conductivity of Kaowool is the same as the actual thermal conductivity. However, if the is a non-zero contact resistance at the contact surfaces, then the effective thermal conductivity of the Kaowool would be lower than its actual thermal conductivity. This was the rationale used to lower the thermal conductivity of Kaowool 1 percent at a time until the calculated temperatures matched measured temperatures.

$$
\begin{aligned}
\sum \mathrm{R}_{\mathrm{th}} & =\frac{\Delta \mathrm{T}}{\mathrm{Q}}=\frac{\Delta \mathrm{x}}{\mathrm{kA}} \\
\mathrm{k}_{\mathrm{eff}} & =\frac{\Delta \mathrm{x}}{\mathrm{A} \sum \mathrm{R}_{\mathrm{th}}}=\frac{\Delta \mathrm{x}}{\mathrm{A}\left\{\left.\mathrm{R}_{\mathrm{th}}\right|_{\text {CONTACT }-\mathrm{A}}+\left.\mathrm{R}_{\mathrm{th}}\right|_{\text {KAOWOOL }}+\left.\mathrm{R}_{\text {th }}\right|_{\text {CONTACT }-\mathrm{B}}\right\}}
\end{aligned}
$$




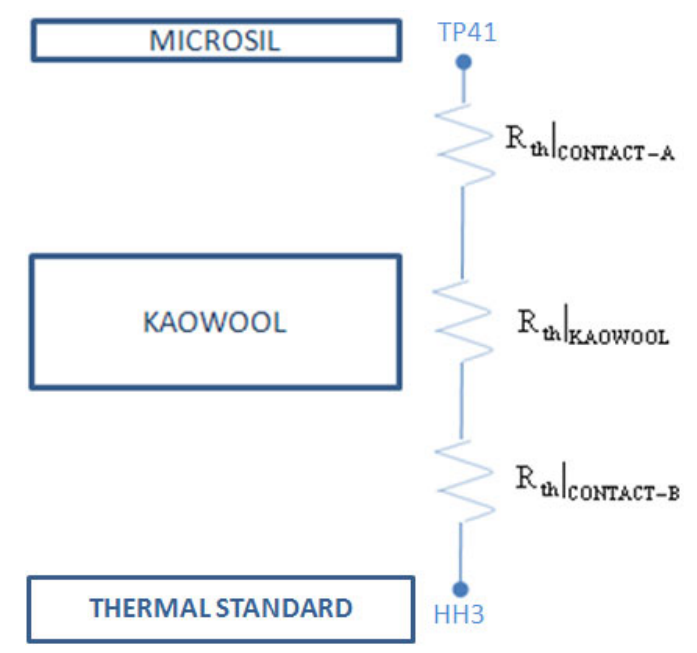

Figure 10.-Contact thermal resistance network.

During the calculations, Grade 4 is used initially and slight modifications are made to it in an effort to fine tune the internal temperatures so they match the experimental data. There is also a $0.016 \mathrm{in}$. alumina disk between the nickel heater block and the heat collector plate. Once the Microsil thermal conductivity is modified to get the absolute value of the internal temperatures in the vicinity of the measured data, modifications to Kaowool and the Alumina disk are made to fine tune the temperatures.

\subsection{Computational Methodology}

The computational methodology consists of two separate calculations. The strategy involves simulating two different experimental tests. Test one is simulated non-operating (insulation loss), and test two is simulated operation via GRCop-84 rod heat rejection. There are no moving parts. For both simulations, slight adjustments are made to the properties of selected materials with the intention of matching internal temperatures observed during experiments. There are various property modifications and temperature mappings that need to be done to complete these calculations, and are discussed in the following sections.

\subsection{Adjustable Parameters}

There are four different parameters that are modified during the course of the calculations. Their modifications are based on the internal temperatures relative to the measured data. The parameters being adjusted are shown in Figure 11, and include Microsil, the alumina disk, and two independent sections of Kaowool. The effects of modifying the properties differ depending on the material being modified. As the thermal conductivity modifications were made during the calculations, the following observations were made with each material:

- Microsil Thermal Conductivity: An increase causes a decrease in heat source and hot-end temperatures.

- Kaowool Thermal Conductivity: An increase causes a decrease in the $\Delta T$ between the heat source and the hot-end.

- Ceramic Paper Thermal Conductivity: An increase causes a decrease in the heat source temperature.

- Thermal Barrier Thermal Conductivity: An increase causes a decrease in the $\Delta T$ between the heat source and the hot-end. 


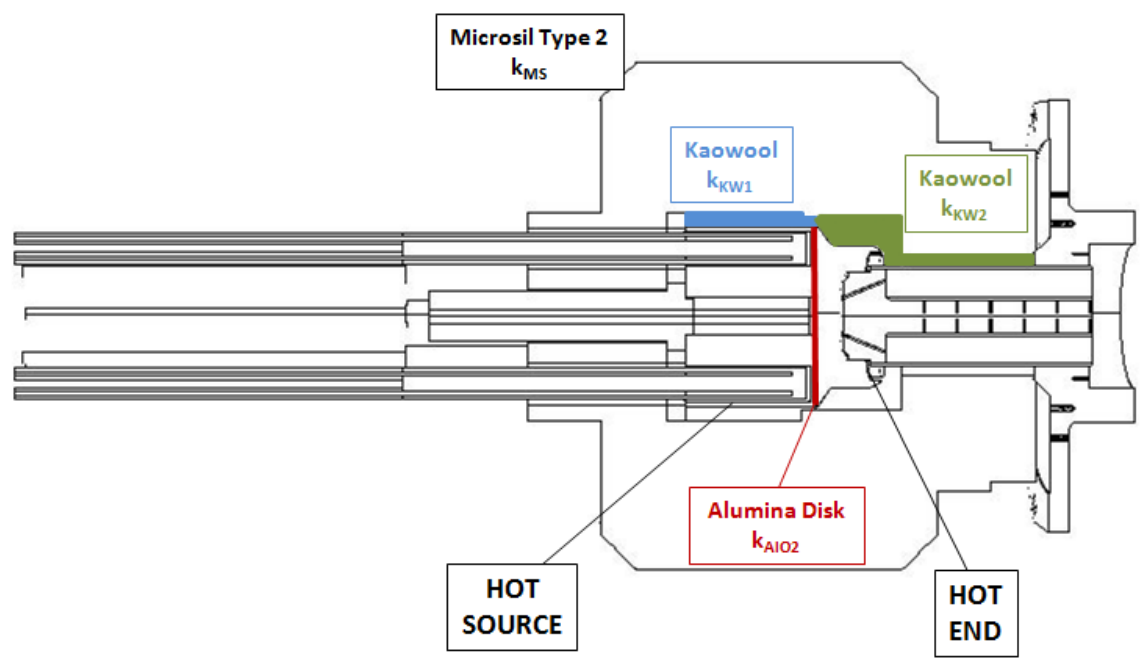

Figure 11.-Materials that are modified during thermal loss simulations.

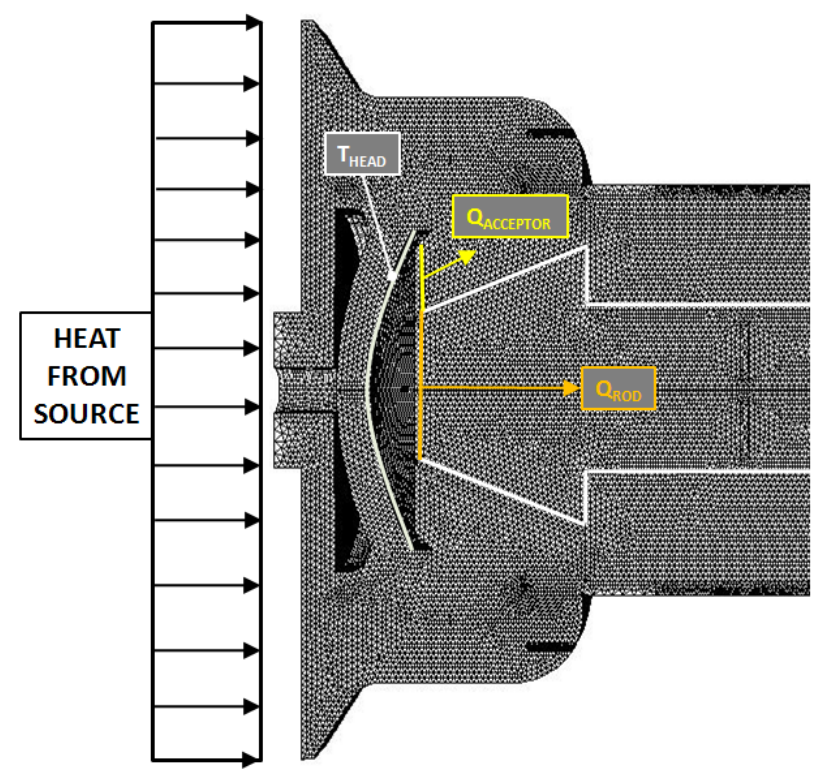

Figure 12.-Portion of heater head used for generation of radiation look-up table.

\subsection{Radiation Lookup Table}

The initial steps in performing calculations with this model were done without accounting for radiation. Activating a radiation model on the full model requires an enormous amount of computational time before the solution converges. Instead, a solution is first obtained without accounting for radiation. Then, a radiation look-up table is applied to account for the radiation across the expansion space (air gap), and the calculation sequences are performed once again, until all of the relevant calculated temperatures match the data obtained from through measurements.

Generation of the radiation lookup table involved making calculations on a reduced version of the Thermal Standard computational model. This model is shown in Figure 12. The insulation and heating packages are not included in this reduced calculation. 
Cold end boundary conditions (obtained from lab measurements) were applied, and a fixed temperature was applied to the heat collector plate. Calculations were then performed with the Discrete Ordinances radiation model activated. Once the solution converged, three items were collected:

1. Area-averaged temperature of the heater head inner wall (where it interfaces with the air)

2. Total heat entering the inner acceptor (where it interfaces with the air)

3. Total heat entering the rod (where it interfaces with the air)

Two radiation look tables were generated because for the insulation loss case, there was Kaowool insulation instead of a copper rod.

\subsection{Procedure}

A flowchart for step 1 of this solution strategy is shown in Figure 13. Step 1 is the simulation of the insulation loss experiment, and the heater head cylinder is filled with Kaowool insulation. Calculations are performed and the temperatures at the heat source and hot end are checked relative to measured data. If the temperatures are high, the thermal conductivity of Microsil is increased. If these temperatures are too low, then it is decreased.

The temperature difference between the heat source and hot end are controlled in a similar manner. If the temperature difference is too big, the thermal conductivity of the alumina disk (thermal barrier) is increased. If it is too low, then the thermal conductivity is lowered. The previously mentioned modifications are typically enough to produce temperatures at the heat source and hot end that match measured data.

Other modifications are required at this point to make sure temperatures at the Microsil-Kaowool interface match measured data. This typically involves a slight modification to the thermal conductivity of the Kaowool. For these calculations, Kaowool was defined as a constant in these two regions and was modified so that in was in the range of $0.20 \mathrm{~W} / \mathrm{m}-\mathrm{K}<\mathrm{k}<0.30 \mathrm{~W} / \mathrm{m}-\mathrm{K}$.

At this point, the temperatures match the measured data, and the radiation look-up table is applied. The area-averaged temperature of the inner heater head dome is extracted from the model and the appropriate heat transfer rate is applied to the surface of the acceptor and the insulation (or rod if this is step 2). All of the previous steps are repeated while constantly updating these boundary conditions until all internal temperatures match measured data. This sometimes involves another adjustment to the Microsil, but it is minor at this point. The resulting Microsil thermal conductivity value is carried over to the second simulation.

A flowchart for step 2 of this solution strategy is shown in Figure 14. In this simulation, the internal Kaowool is replaced with a GRCop-84 rod and Microsil is not allowed to change. The internal acceptor and the GRCop-84 rod are not in direct contact as they are separated by a thin layer of ceramic paper. When the thermal conductivity of the ceramic paper is increased ( $<1$ percent at a time), the temperatures of the heat source and hot end decrease, while increasing the amount of heat rejected by the rod. The opposite is also true. For step two, the ceramic paper thermal conductivity modification serves the same purpose as the Microsil adjustment in step one. All other adjustments are done in the same way for the same purpose as step 1 . 


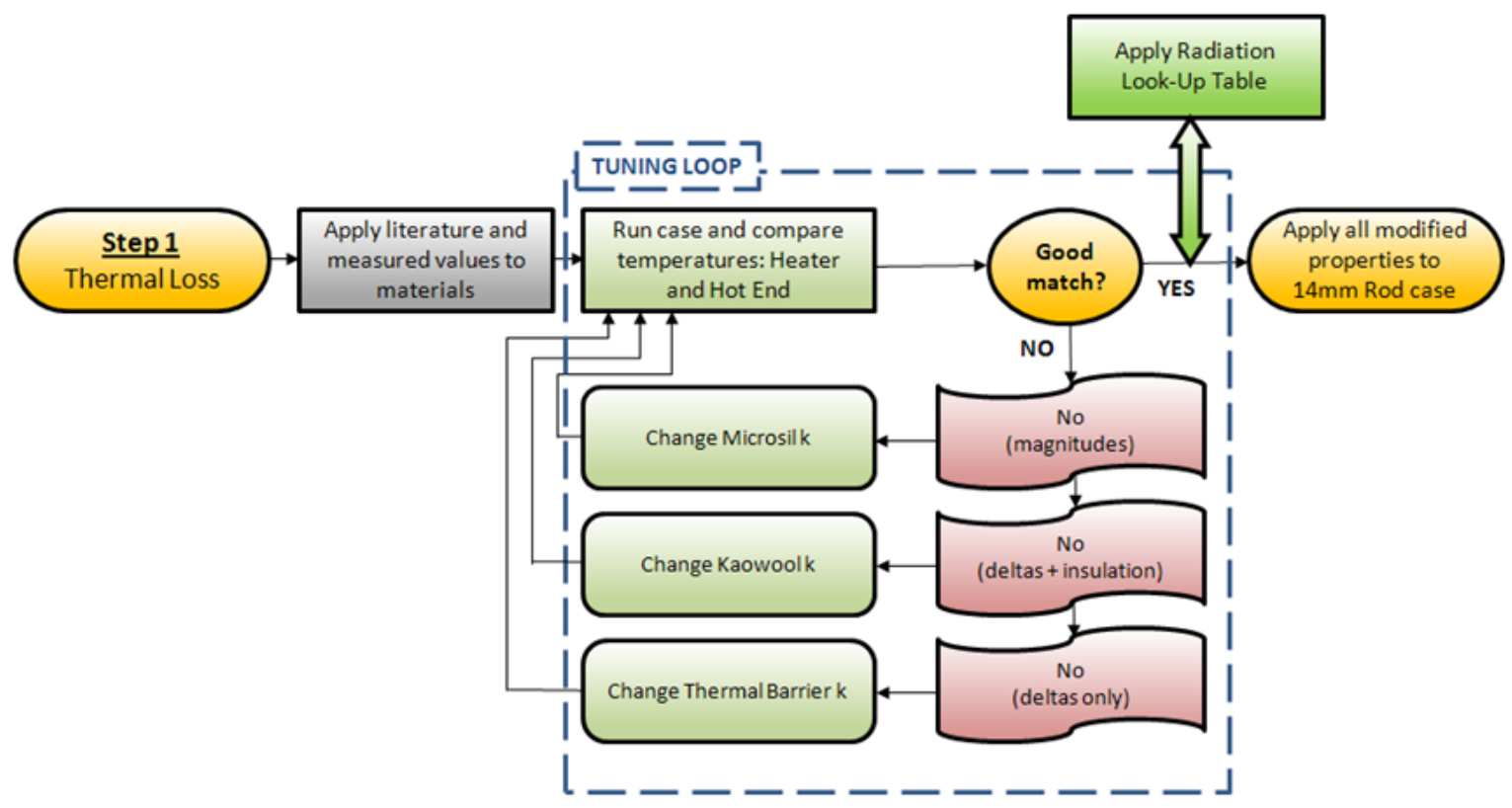

Figure 13.-Step 1: Determination of Microsil thermal conductivity.

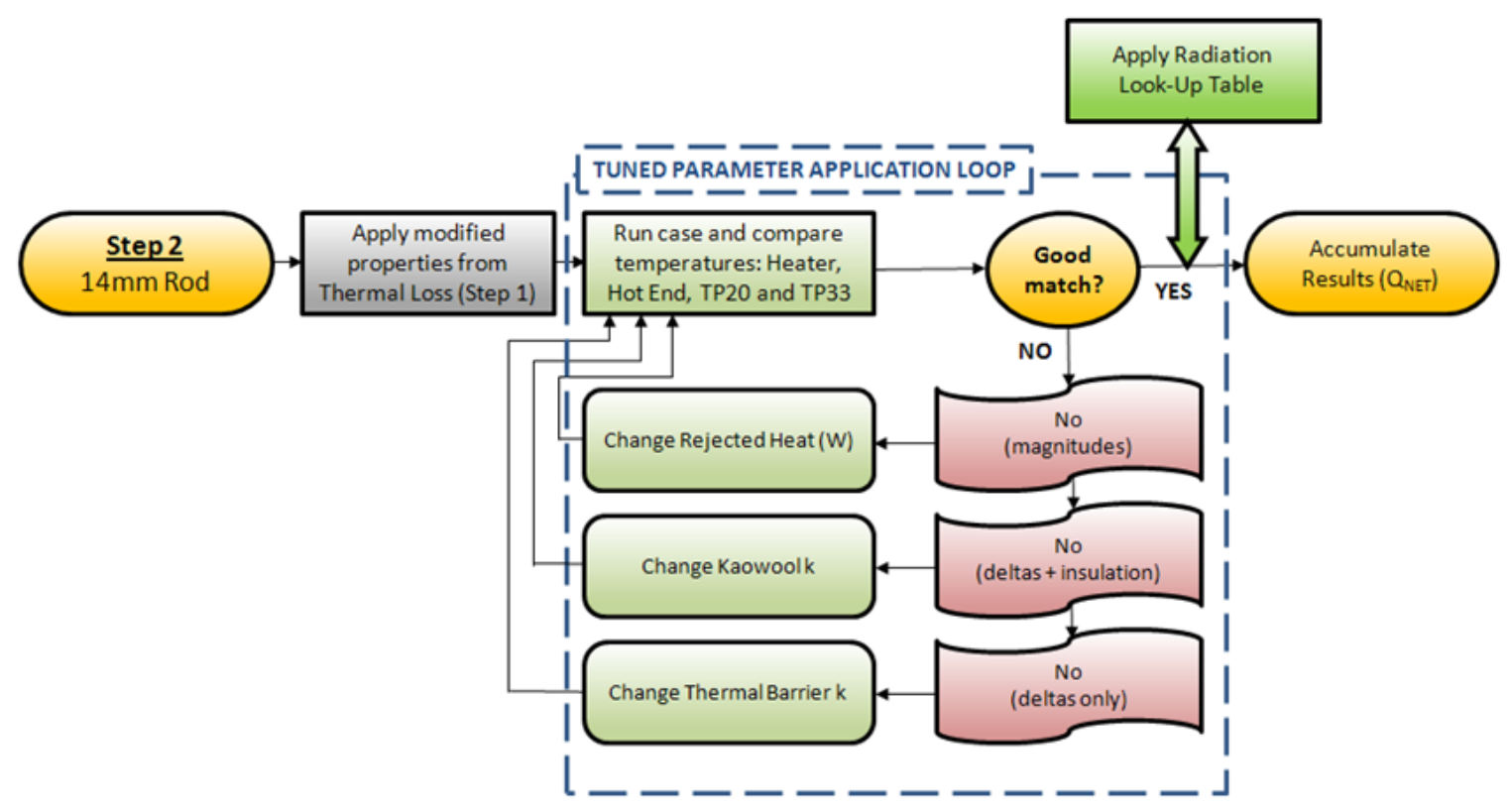

Figure 14.-Step 2: Determination of net heat input. 


\subsection{Available Test Data}

A variety of experimental measurements were made to establish the thermal gradients throughout the test hardware. The locations of these temperature measurements are shown in Figure 15. The details of the experimental test and results are available (Ref. 12), but not described in this document.

\subsection{Experimental Temperature Mapping}

The external surface temperatures of the measured data are used to create the model boundary conditions. The measured temperatures and their intended position on the model are used to generate a curve fit equation, which is then directly mapped onto the model and held fixed during the duration of the calculations. Temperature mappings on faces were done in a similar manner and resulted in constant, linear, or nonlinear temperature profiles depending on the number of measurements on a particular surface.

\subsection{Lead Wire Temperature Mapping}

An infrared (IR) camera was used to collect pictures of the lead wires and the exposed fire rods during testing. The post-processing of these IR images provided a temperature profile as a function of position, which was then mapped onto the external surface of the lead wire outer sheath. The temperature profile curve-fit was defined as a quadratic equation.

\subsection{Gross Heat Input}

Gross heat input produced by the fire rods was recorded during the laboratory experiments. This value was used to set the boundary condition of the computational fire rod. The target gross heat was divided by the total volume of the computational heating elements, producing a heat generation rate in $\mathrm{W} / \mathrm{m}^{3}$. This value was applied to all of the heating elements as a boundary condition. Figure 16 shows the cross section of an actual fire rod as it is compared to the solution volumes of the computational fire rod.

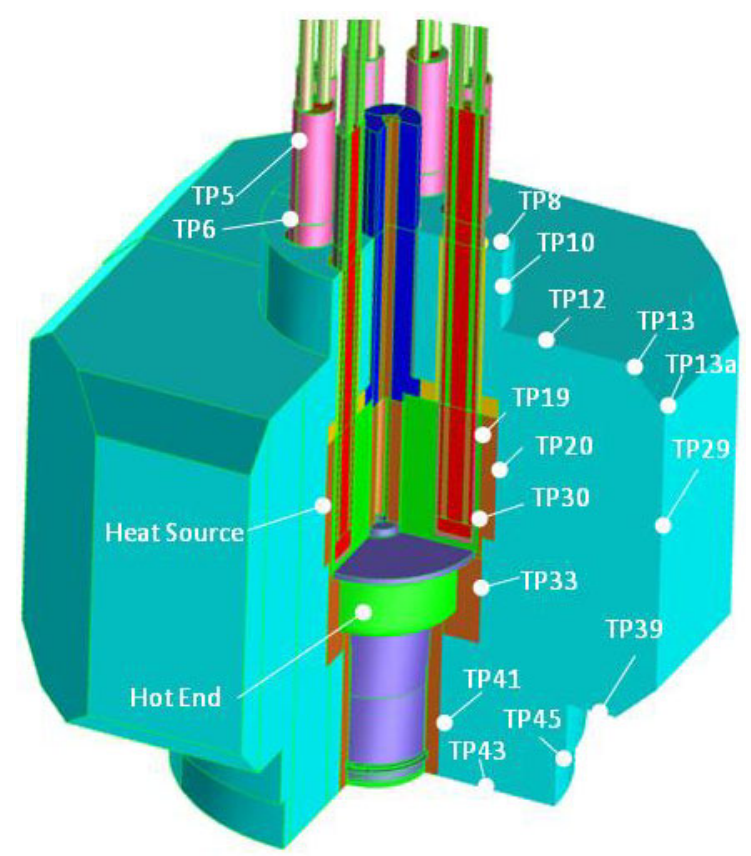

Figure 15.-Measurement locations in thermal standard computational model. 


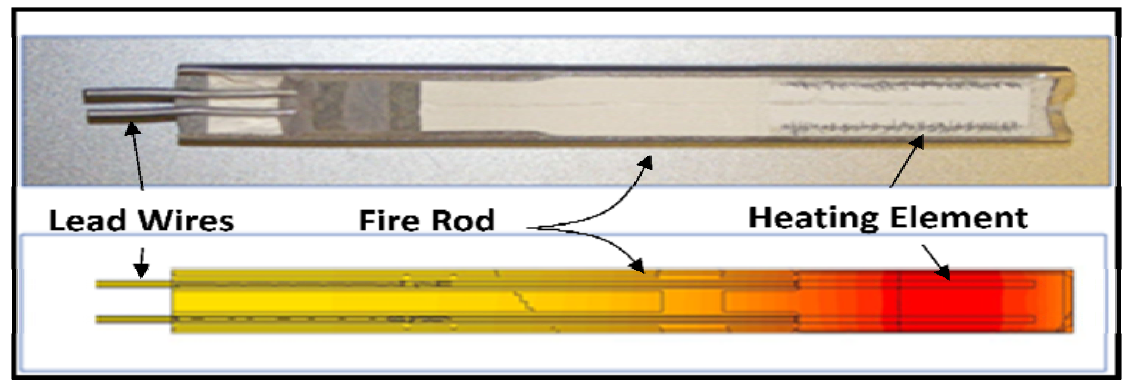

Figure 16.-Fire rod hardware and simulation geometry.

\subsection{Results}

The solution strategy was applied to the simulated non-operating (no rod) case. After application of the radiation look-up table was completed and matching of the internal temperatures was verified, the resulting Microsil thermal conductivity was 5 percent above the value measured by TPRL (Thermophysical Property Research Laboratory, Inc.).

This value of Microsil (TPRL plus 5 percent) was then applied to the second simulation. The internal Kaowool was replaced with a GRCop-84 rod. The heat generation rate on the fire rods and the external temperature boundary conditions were updated with the appropriate boundary conditions for the simulated operation (14 mm rod) case.

While holding the Microsil properties fixed, the solution strategy was applied until internal temperatures matched experimental data.

Figure 17 shows the calculated and measured temperatures at the Kaowool-Microsil interface, and the external surface of the nickel heater block. The largest temperature difference is at TP41. Calculated values are $\sim 17^{\circ} \mathrm{C}$ lower than the measured data. In this model, Kaowool was divided into three volumes. One volume is adjacent to the nickel block, the second to the heat collector and the third to the heater head cylinder. Adjustments to each block of Kaowool controlled each temperature at TP20, TP33, and TP41.

Figure 18 shows the calculated and measured temperatures along the heater head cylinder's exterior wall. Heater head (HH) locations 1 to 4 were measured during laboratory experimentation. The largest difference between calculations and measurements is at HH2. Predictions at this location were $12{ }^{\circ} \mathrm{C}$ lower than what was measured in the lab.

Figure 19 shows the calculated and measured temperatures along the GRCop-84 centerline. Stirling rod (SR) locations 1 to 6 were measured during laboratory experiments. The largest difference between calculations and measurements is at SR1. Predictions at this position were $9{ }^{\circ} \mathrm{C}$ lower than what was measured.

When this set of calculations was completed, the $14 \mathrm{~mm}$ rod was rejecting $205.5 \mathrm{~W}$ of heat and the cold end was rejecting $34.8 \mathrm{~W}$ of heat. When compared to the values obtained in the lab (208.7 and $35.7 \mathrm{~W}$, respectively), the calculations were 1.7 percent lower. Heat distribution results can be seen in Figure 20.

At the end of these calculations, the final temperatures at the heat source and the hot end were:

$$
\begin{array}{lll}
\mathrm{T}_{\text {HEAT SOURCE }} & =994.5^{\circ} \mathrm{C} & \text { (target } 995.5^{\circ} \mathrm{C} \text { ) } \\
\mathrm{T}_{\text {HOT-END }} & =844.1^{\circ} \mathrm{C} & \left(\text { target } 844.8{ }^{\circ} \mathrm{C}\right. \text { ) }
\end{array}
$$

Because contact resistances were not included in this model, there effects were absorbed into $\mathrm{k}_{\mathrm{W} 1}$ and $\mathrm{k}_{\mathrm{AlO} 2}$, resulting in an adjustment that would make the effective thermal conductivities lower. 


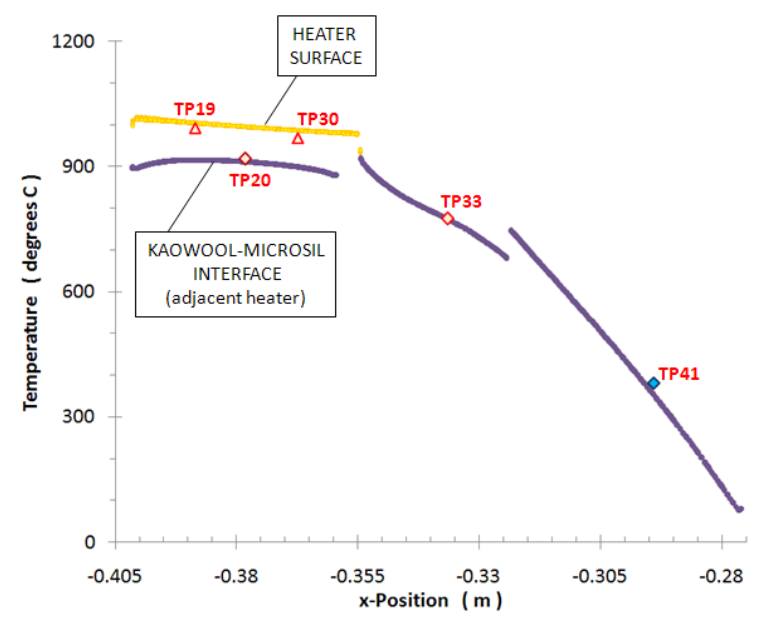

Figure 17.-Temperatures on KaowoolMicrosil interface and nickel heater block surface.

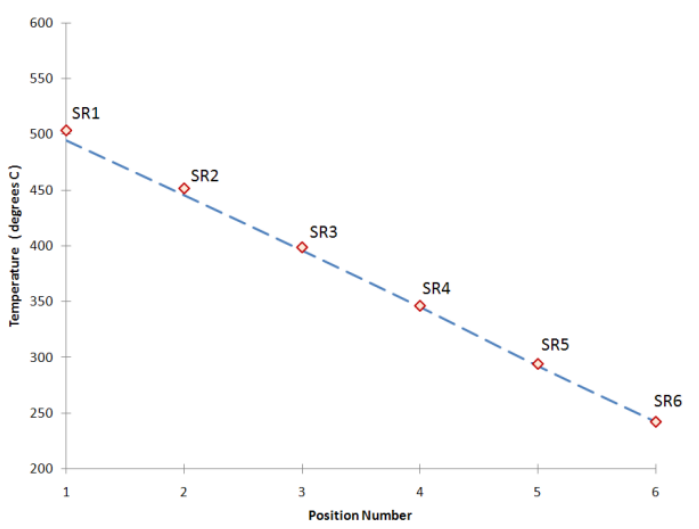

Figure 19.-Temperatures along the centerline of the GRCop-84 rod.

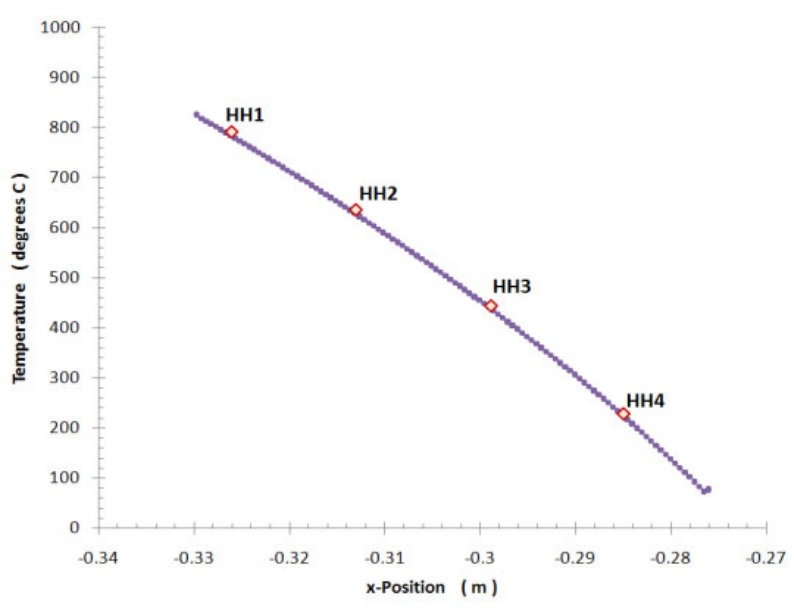

Figure 18.-Temperatures on the external surface of the heater head cylinder.

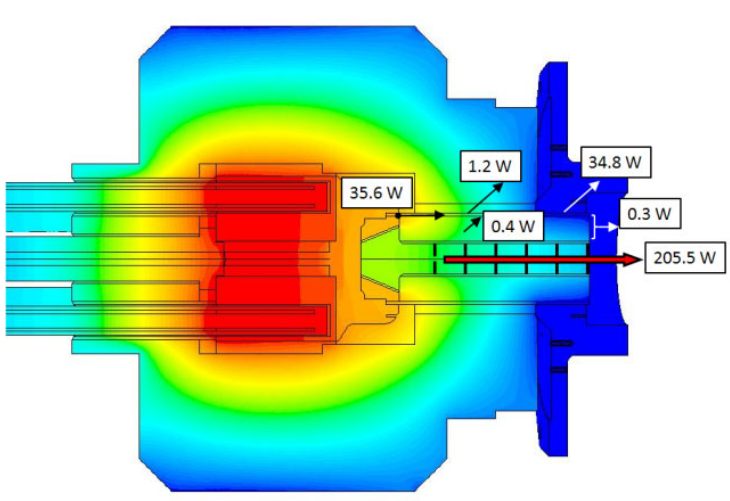

Figure 20.-Calculated heat distribution for simulated operation case. 


\subsection{Conclusions}

Convertor and generator testing is carried out in tests designed to characterize convertor performance when subjected to environments intended to simulate launch and space conditions. The value of net heat input must be known in order to calculate convertor efficiency. In an effort to improve the accuracy of the efficiency calculation, numerous tasks have been performed which provided a more accurate value for net heat input into the ASCs, including the use of multi-dimensional numerical models to predict net heat input. This effort produced a methodology for making net heat input predictions, which was successfully validated using specially designed test hardware enabling measurement of heat transferred through a simulated Stirling cycle. This methodology will be applied to future ASC convertors to obtain values for net heat input.

\section{References}

1. Beale, W.T., "Free Piston Stirling Engines - Some Model Tests and Simulations,” [Preliminary investigations of free-piston Stirling engines], SAE International Automotive Engineering Conference, January 1969.

2. Wilson, S.D., Reid, T.V., Schifer, N.A. and Briggs, M.H., "Overview of Heat Addition and Efficiency Predictions for an Advanced Stirling Convertor,” Proceedings of the Ninth International Energy Conversion Engineering Conference (IECEC 2011), American Institute for Aeronautics and Astronautics, 2011.

3. Schreiber, J.G., "Development Considerations on the Free-Piston Stirling Power Convertor for Use in Space," Fourth International Energy Conversion Engineering Conference, AIAA Paper 20064015, AIAA, San Diego, CA, June 2006.

4. Thieme, L.G. and Schreiber, J.G., "Supporting Development for the Stirling Radioisotope Generator and Advanced Stirling Technology Development at NASA Glenn,” NASA/TM 213409, February 2005.

5. Tew, R.C., Dyson, R.W., Wilson, S.D., and Demko R., “Overview 2004 of NASA-Stirling Convertor CFD Model Development and Regenerator R\&D Efforts,” NASA/TM - 213404, NASA GRC, Cleveland, OH, November 2004.

6. Dyson, R.W, Wilson, S.D., Tew, R.C., Demko, R., "On the Need for Multidimensional Stirling Simulations,” Third International Energy Conversion Engineering Conference, AIAA Paper 20055557, AIAA, San Francisco, CA, August 2005.

7. Gedeon, D., “Sage - Object-oriented software for Stirling machine design,” AIAA Paper 94-4106, 1994.

8. Gedeon, D., “Sage: Stirling-Cycle Model Class Reference, Third Ed.,” Gedeon Associatates, 1999.

9. Gedeon, D., “Sage: User’s Guide, Third Edition,” Gedeon Associates, 1999.

10. Cengel, Y.A., Boles, M.A., Thermodynamics: An Engineering Approach, New York, McGraw-Hill Inc., 1989, Chaps. 5-8.

11. Ellis, D.L., "GRCop-84: A High-Temperature Copper Alloy for High-Heat-Flux Applications,” NASA/TM-2005-213566, NASA GRC, Cleveland, OH, 2005.

12. Briggs, M.H., "Development of a Thermal Standard Used for Model Verification of Net Heat Input Simulations for the Advanced Stirling Convertor,” Proceedings of the Ninth International Energy Conversion Engineering Conference (IECEC 2011), American Institute for Aeronautics and Astronautics, 2011. 


\begin{tabular}{|c|c|c|}
\hline \multicolumn{2}{|c|}{ REPORT DOCUMENTATION PAGE } & $\begin{array}{l}\text { Form Approved } \\
\text { OMB No. 0704-0188 }\end{array}$ \\
\hline \multicolumn{3}{|c|}{ 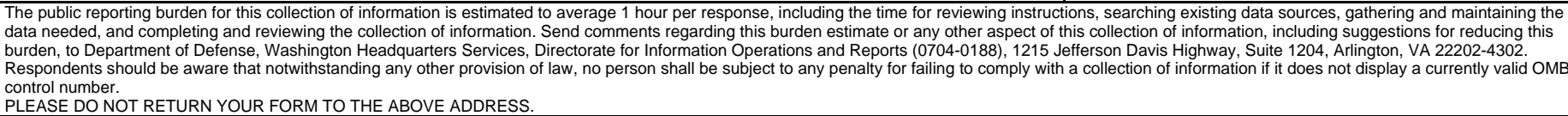 } \\
\hline $\begin{array}{l}\text { 1. REPORT DATE (DD-MM-YYYY) } \\
01-04-2012\end{array}$ & $\begin{array}{l}\text { 2. REPORT TYPE } \\
\text { Technical Memorandum }\end{array}$ & 3. DATES COVERED (From - To) \\
\hline \multirow{3}{*}{\multicolumn{2}{|c|}{$\begin{array}{l}\text { 4. TITLE AND SUBTITLE } \\
\text { A Computational Methodology for Simulating Thermal Loss Testing of the Advanced } \\
\text { Stirling Convertor }\end{array}$}} & 5a. CONTRACT NUMBER \\
\hline & & 5b. GRANT NUMBER \\
\hline & & 5c. PROGRAM ELEMENT NUMBER \\
\hline \multirow{3}{*}{\multicolumn{2}{|c|}{$\begin{array}{l}\text { 6. AUTHOR(S) } \\
\text { Reid, Terry, V.; Wilson, Scott, D.; Schifer, Nicholas, A.; Briggs, Maxwell, H. }\end{array}$}} & 5d. PROJECT NUMBER \\
\hline & & 5e. TASK NUMBER \\
\hline & & $\begin{array}{l}\text { 5f. WORK UNIT NUMBER } \\
\text { WBS 138494.05.02.04.01 }\end{array}$ \\
\hline \multicolumn{2}{|c|}{$\begin{array}{l}\text { 7. PERFORMING ORGANIZATION NAME(S) AND ADDRESS(ES) } \\
\text { National Aeronautics and Space Administration } \\
\text { John H. Glenn Research Center at Lewis Field } \\
\text { Cleveland, Ohio 44135-3191 }\end{array}$} & $\begin{array}{l}\text { 8. PERFORMING ORGANIZATION } \\
\text { REPORT NUMBER } \\
\text { E-17822 }\end{array}$ \\
\hline \multirow{2}{*}{\multicolumn{2}{|c|}{$\begin{array}{l}\text { 9. SPONSORING/MONITORING AGENCY NAME(S) AND ADDRESS(ES) } \\
\text { National Aeronautics and Space Administration } \\
\text { Washington, DC 20546-0001 }\end{array}$}} & $\begin{array}{l}\text { 10. SPONSORING/MONITOR'S } \\
\text { ACRONYM(S) } \\
\text { NASA }\end{array}$ \\
\hline & & $\begin{array}{l}\text { 11. SPONSORING/MONITORING } \\
\text { REPORT NUMBER } \\
\text { NASA/TM-2012-217287 }\end{array}$ \\
\hline \multicolumn{3}{|c|}{$\begin{array}{l}\text { 12. DISTRIBUTION/AVAILABILITY STATEMENT } \\
\text { Unclassified-Unlimited } \\
\text { Subject Category: } 20 \\
\text { Available electronically at http://www.sti.nasa.gov } \\
\text { This publication is available from the NASA Center for AeroSpace Information, 443-757-5802 }\end{array}$} \\
\hline
\end{tabular}

\section{SUPPLEMENTARY NOTES}

\section{ABSTRACT}

The U.S. Department of Energy (DOE) and Lockheed Martin Space Systems Company (LMSSC) have been developing the Advanced Stirling Radioisotope Generator (ASRG) for use as a power system for space science missions. This generator would use two highefficiency Advanced Stirling Convertors (ASCs), developed by Sunpower Inc. and NASA Glenn Research Center (GRC). The ASCs convert thermal energy from a radioisotope heat source into electricity. As part of ground testing of these ASCs, different operating conditions are used to simulate expected mission conditions. These conditions require achieving a particular operating frequency, hot end and cold end temperatures, and specified electrical power output for a given net heat input. In an effort to improve net heat input predictions, numerous tasks have been performed which provided a more accurate value for net heat input into the ASCs, including the use of multidimensional numerical models. Validation test hardware has also been used to provide a direct comparison of numerical results and validate the multi-dimensional numerical models used to predict convertor net heat input and efficiency. These validation tests were designed to simulate the temperature profile of an operating Stirling convertor and resulted in a measured net heat input of $244.4 \mathrm{~W}$. The methodology was applied to the multi-dimensional numerical model which resulted in a net heat input of $240.3 \mathrm{~W}$. The computational methodology resulted in a value of net heat input that was 1.7 percent less than that measured during laboratory testing. The resulting computational methodology and results are discussed.

\section{SUBJECT TERMS}

Computational Fluid Dynamics (CFD); Heat transfer; Stirling convertor

\begin{tabular}{|c|c|c|c|c|c|}
\hline \multicolumn{3}{|c|}{ 16. SECURITY CLASSIFICATION OF: } & \multirow{2}{*}{$\begin{array}{l}\text { 17. LIMITATION OF } \\
\text { ABSTRACT } \\
\text { UU }\end{array}$} & \multirow{2}{*}{$\begin{array}{l}\text { 18. NUMBER } \\
\text { OF } \\
\text { PAGES } \\
21\end{array}$} & \multirow{2}{*}{$\begin{array}{l}\text { 19a. NAME OF RESPONSIBLE PERSON } \\
\text { STI Help Desk (email:help@sti.nasa.gov) } \\
\text { 19b. TELEPHONE NUMBER (include area code) } \\
\text { 443-757-5802 }\end{array}$} \\
\hline $\begin{array}{l}\text { a. REPORT } \\
U\end{array}$ & $\begin{array}{l}\text { b. ABSTRACT } \\
U\end{array}$ & $\begin{array}{l}\text { c. THIS } \\
\text { PAGE } \\
\text { U }\end{array}$ & & & \\
\hline
\end{tabular}


